\title{
Correction to: Application of 1D and 2D hydrodynamic modeling to study glacial lake outburst flood (GLOF) and its impact on a hydropower station in Central Himalaya
}

\author{
Ashim Sattar ${ }^{1,2}$ - Ajanta Goswami ${ }^{2} \cdot$ Anil V. Kulkarni $^{3}$
}

Published online: 14 August 2019

(c) Springer Nature B.V. 2019

\section{Correction to: Natural Hazards https://doi.org/10.1007/s11069-019-03657-6}

The article was published with the citation "Worni et al. (2012)". The author group of the article would like readers to know that this information should instead read/be as follows: "Worni et al. (2013)"-Worni R, Huggel C, Stoffel M (2013) Glacial lakes in the Indian Himalayas - from an area-wide glacial lake inventory to on-site and modeling based risk assessment of critical glacial lakes. Sci Total Environ 468:S71-S84. https://doi. org/10.1016/j.scitotenv.2012.11.043. This correction stands to correct the original article.

Publisher's Note Springer Nature remains neutral with regard to jurisdictional claims in published maps and institutional affiliations.

The original article can be found online at https://doi.org/10.1007/s11069-019-03657-6.

Ashim Sattar

ashim.sattar@gmail.com

$1 \quad$ NIIT University, Rajasthan 301705, India

2 Indian Institute of Technology Roorkee, Roorkee 247667, India

3 Indian Institute of Science, Bangalore 560012, India 